\title{
Analisis Masalah Guru dan Siswa terhadap Perangkat Pembelajaran Biologi Berbasis Group Investigation untuk Meningkatkan Kemampuan Berpikir Kritis Siswa
}

\section{Teacher and Student Problem Analysis of Group Investigation-Based Biology Learning Tools to Improve Students' Critical Thinking Abilities}

\author{
WA SURIATI ${ }^{*}$, ELSJE THEODORA MAASAWET ${ }^{1}$, SONJA V.T. LUMOWA ${ }^{1}$ \\ ${ }^{1}$ Program Studi Pendidikan Biologi, Magister Keguruan Biologi, Fakultas Keguruan dan Ilmu Pendidikan. Universitas Mulawarman. \\ Indonesia \\ *Corresponding authors: wa.suriati17@gmail.com
}

Manuscript received: ......... Revision accepted:

\begin{abstract}
Tujuan penelitian ini adalah untuk memperoleh 1) pemahaman guru terkait perangkat pembelajaran biologi berbasis Group Investigation dan kemampuan berpikir kritis, 2) gambaran kemampuan siswa dalam berpikir kritis, 3) solusi dalam mengatasi permasalahan guru dan siswa terkait pembelajaran berbasis group invetigation. Pemahaman guru dan siswa diperoleh dengan wawancara dan angket dianalisis secara deskriptif kualitatif. Hasil penelitian ini diketahui bahwa: 1) pemahaman guru biologi terkait perangkat pembelajaran biologi berbasis group investigation masih kurang sehingga proses pembelajaran kurang optimal, 2) guru biologi masih mengalami kesulitan dalam mengembangkan perangkat pembelajaran sehingga memerlukan sosialisasi, 3) berpikir kritis siswa dalam pembelajaran masih kurang, 4) perlu adanya arahan dan bimbingan untuk mengembangkan perangkat pembelajaran. Sampel pengamatan pada analisis ini adalah guru dan siswa di SMAN 6 Penajam Paser Utara. Hasil pengamatan menunjukkan sebanyak 75,10\% guru mengalami kendala dalam mengembangkan perangkat pembelajaran. Guru menyatakan bahwa siswa di kelas kurang berpikir kritis sebesar $71,20 \%$.
\end{abstract}

Keywords: Model Group Investigation, Berpikir Kritis

\section{PENDAHULUAN}

Pendidikan dikatakan bermutu jika proses pembelajaran dikelas berlangsung dengan efektif dan siswa mampu menguasai materi dengan baik (Sani, 2013). Pendidikan merupakan hal yang sangat penting dalam mempersiapkan masa depan seorang siswa untuk menjadi lebih baik. Dinamika perkembangan zaman semakin diwarnai oleh persaingan yang sangat ketat, dimana menuntut manusia untuk mempunyai kesiapan dan daya tahan yang tinggi, sehingga apapun yang dihadapi dapat dilaksanakan dengan baik tanpa adanya kendala yang berarti. Selain itu, pendidikan akan menyebabkan siswa secara aktif dapat mengembangkan potensi dirinya, untuk memiliki kecerdasan, berakhlak mulia, serta memiliki keterampilan yang berguna bagi dirinya sendiri, masyarakat, maupun bangsa dan negaranya (Permendiknas No. 41 Tahun 2007).

Perkembangan iptek dan tantangan global yang dinamis, diperlukan pula inovasi dan upaya pengembangan perangkat pembelajaran yang tepat sehingga dapat menstimulasi kemampuan berfikir kritis siswa. Keterampilan berfikir kritis diperlukan untuk meningkatkan daya saing siswa yang diimbangi dengan karakter positif, agar potensi siswa bisa berkembang secara seimbang dan harmonis. Tuntutan tersebut tentunya harus dibarengi dengan perubahan dalam pembelajaran yang tadinya berpusat pada guru (teacher centered) menjadi pembelajaran yang berpusat pada siswa (learning centered) perubahan ini diharapkan dapat mendorong siswa untuk terlibat secara aktif dalam membangun pengetahuan, sikap dan prilaku. Melalui proses pembelajaran dengan keterlibatan aktif siswa ini, berarti guru tidak mengambil hak siswa untuk belajar.

Penggunaan model pembelajaran yang tepat dan disesuaikan dengan tujuan pembelajaran diharapkan akan menghasilkan prestasi belajar yang lebih baik. Suatu model pembelajaran, khususnya pada mata pelajaran biologi belum tentu sesuai untuk setiap kompetensi dasar. Sehingga diperlukan inovasi dalam memilih model pembelajaran yang tepat dengan materi pembelajaran yang disajikan, agar terjadi proses pembelajaran yang komunikatif antara guru dan siswa. Untuk mencapai tujuan pembelajaran tersebut diperlukan suatu model pembelajaran yang sesuai dengan tujuan pendidikan, fasilitas, karakteristik siswa, guru, dan materi pelajaran.

Realita yang terjadi menunjukkan pengembangan perangkat pembelajaran di sekolah belum terlaksana dengan optimal karena guru masih bingung dan beban tugas yang banyak. Kurangnya refrensi dan pelatihan untuk guru. Solusinya adalah dengan melakukan penelitian pengembangan perangkat pembelajaran yang dimiliki oleh guru sehingga dapat dijadikan referensi bagi guru untuk mengembangkan perangkat sendiri. 
Perangkat pembelajaran merupakan hal yang harus disiapkan oleh guru sebelum melaksanakan pembelajaran. Dalam KBBI (2007), perangkat adalah alat atau perlengkapan, sedangkan pembelajaran adalah proses atau cara menjadikan orang belajar. Menurut Zuhdan, dkk (2011) perangkat pembelajaran adalah alat atau perlengkapan untuk melaksanakan proses yang memungkinkan pendidik dan peserta didik melakukan kegiatan pembelajaran.

Perangkat pembelajaran menjadi pegangan bagi guru dalam melaksanakan pembelajaran baik di kelas, laboratorium atau di luar kelas. Dalam Permendikbud No. 65 Tahun 2013 tentang Standar Proses Pendidikan Dasar dan Menengah disebutkan bahwa penyusunan perangkat pembelajaran merupakan bagian dari perencanaan pembelajaran.

Fakta dilapangan menunjukkan bahwa proses pembelajaran yang dilakukan dikelas masih menggunakan pembelajaran ceramah, menulis dan tugas. Sehingga siswa kurang terlibat aktif dan berpikir kritis dalam pembelajaran. Hal tersebut menjadikan siswa bercanda dengan teman sebangku, kurang memperhatikan guru, kemampuan berpikir kritis yang dimiliki kurang maksimal.

Belajar mengajar di kelas seharusnya menggunakan model group investigation supaya terlibat aktif berdiskusi dan terlibat dalam kegiatan pembelajaran. Model pengembangan perangkat pembelajaran yang digunakan dalam penelitian ini adalah model Plomp. Adapun fase-fase yang akan dilakukan dalam penelitian ini ada lima yaitu fase investigasi awal (preliminary investigation); fase desain (design); fase realisasi/ konstruksi (realization /construction); fase tes, evaluasi, dan revisi (test, evaluation, and revision); dan fase implementasi (implementation).

Sanjaya (2006) menyatakan bahwa selama ini pada semua mata pelajaran termasuk sains (biologi) tidak dapat mengembangkan kemampuan anak untuk berpikir kritis dan sistematis karena strategi pembelajaran berpikir tidak digunakan secara baik di dalam kelas.

Perangkat pembelajaran merupakan panduan atau pemberi arah bagi seorang guru. Hal tersebut penting karena proses pembelajaran adalah sesuatu yang sistematis dan terpola. Proses belajar mengajar sehari-hari tidak terlepas dari komponen-komponen perangkat pembelajaran yang relevan yaitu, silabus, rpp, materi ajar, lembar kerja siswa, dan evaluasi/ penilaian. Pada realita sekarang masih banyak guru yang bingung ditengah-tengah proses pembelajaran hanya karena tidak memiliki perangkat pembelajaran. Oleh karena itu, perangkat pembelajaran memberi panduan apa yang harus dilakukan seorang guru di dalam kelas. Selain itu dengan mengembangkan perangkat pembelajaran yang dimiliki akan memberikan kemampuan bagi guru untuk mengembangkan teknik mengajar dan menjadi dasar untuk merancang perangkat yang lebih baik.

Realita di lapangan menunjukkan sebagian besar pembelajaran biologi di sekolah-sekolah masih mengikuti pola-pola pembelajaran konvensional. Metode ceramah masih menjadi cara yang dipilih karena dengan menggunakan metode tersebut guru tidak perlu mempersiapkan perangkat secara detail.

Berdasarkan latar belakang tersebut, pada penelitian ini diperlukan analisis yang lebih mendalam sebagai kajian dalam pengembangan perangkat pembelajaran berbasis group investigation untuk meningkatkan kemampuan berpikir kritis. Rumusan masalah dalam penelitian ini adalah: 1) bagaimana permasalahan guru terkait perangkat pembelajaran berbasis model group investigation? 2) bagaimana kemampuan berpikir kritis siswa dalam pembelajaran? 3) bagiamana solusi mengatasi permasalahan yang dialami oleh guru dan siswa?

\section{METODE PENELITAN}

Metode penelitian ini menggunakan metode Research and Development (R\&D). Hanya terbatas pada analisis permasalahan guru dan siswa SMAN 6 PPU. Penelitian ini khusus untuk mengidentifikasi permasalahan yang terjadi tehadap guru dan siswa. Teknik pengumpulan data menggunakan metode wawancara dan angket. Sampel pengamatan pada analisis ini adalah guru dan siswa di SMAN 6 Penajam Paser Utara.

\section{HASIL DAN PEMBAHASAN}

Berdasarkan observasi dan wawancara di SMAN 6 Penajam Paser Utara didapatkan temuan sebagai berikut: 1) guru belum pernah mengembangkan perangkat pembelajaran; (2) guru tidak memiliki refrensi dan belum pernah ada pelatihan dalam pengembangan perangkat;(3) siswa masih pasif dan kurang berpikir kritis; (4) metode ceramah dan mencatat lebih sering digunakan; (5) sarana dan prasarana kurang memadai, (6) guru kurang inovatif dalam memberikan praktik; (7) siswa jenuh dan kurang tertantang dalam belajar; (8) hasil belajar siswa sebaian besar masih kurang dari standar yang ditentukan.

Secara umum pengimplementasian perangkat pembelajaraan pada proses belajar mengajar telah berjalan namun karena pilihan model pembelajaran masih sangat terbatas, sehingga proses belajar mengajar cenderung bersifat monoton, peran guru yang lebih dominan dalam aktivitas pembelajaran menyebabkan siswa menjadi pasif. Dari aspek penggunaan media pembelajaran, para guru bidang studi biologi pada umumnya menggunakan metode ceramah yang merupakan elaborasi dari model pengajaran langsung, walaupun sesekali telah menggunakan media visual dan perangkat laboratorium secara terbatas pada pokok bahasan tertentu.

Perangkat pembelajaran menjadi pegangan bagi guru dalam melaksanakan pembelajaran baik di kelas, laboratorium atau di luar kelas. Dalam Permendikbud No. 65 Tahun 2013 tentang Standar Proses Pendidikan Dasar dan Menengah disebutkan bahwa penyusunan perangkat pembelajaran merupakan bagian dari perencanaan pembelajaran. 


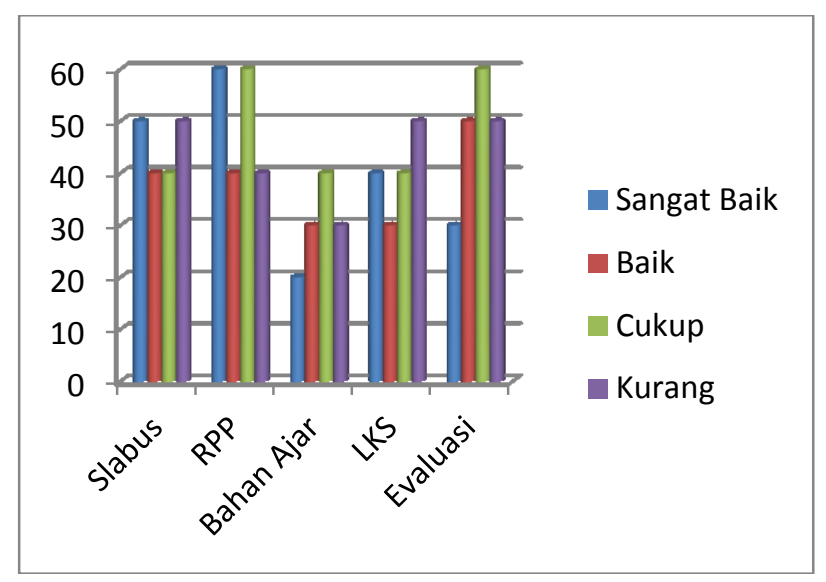

Gambar 1 Rekapitulasi pemahaman guru terkait perangkat pembelajaran

Berdasarkan pengamatan bahwasanya proses pembelajaran yang terjadi dikelas belum maksimal. Pernyataan tersebut dibenarkan guru biologi bahwasanya guru masih cenderung menerapkan metode konvensional dan monoton sehingga menemui kesulitan dalam menyusun perangkat pembelajaran Rencana Pelaksanaan Pembelajaran, bahan ajar, media pembelajaran, lembar kerja siswa dan assessment/ evaluasi. Hasil pengamatan menunjukkan sebanyak $78,15 \%$ guru mengalami kendala dalam mengembangkan perangkat pembelajaran. Guru menyatakan bahwa siswa di kelas kurang berpikir kritis sebesar $70,10 \%$.

Dari data yang didapatkan sebanyak $50 \%$ guru belum paham isi silabus dikategorikan dengan "kurang" karena tidak mau mencari dan membuat silabus sehingga kurang mengerti tujuan dari pembuatan silabus. Sebanyak $60 \%$ guru sudah memahami isi rencana pelaksanaan pembelajaran, hal ini dikarenakan guru dituntut untuk aktif dan harus menyesuaikan dengan kurikulum terbaru supaya tidak terjadi kesalahan dalam mengajar. Sebanyak $40 \%$ guru yang memahami isi bahan ajar dikategorikan masih "kurang", hal ini dikarenakan guru lebih memilih menggunakan buku paket dan kurang berinovasi. Sebanyak $50 \%$ guru memahami isi dari lembar kerja siswa dikategorikan dengan masih "kurang", hal ini dikarenakan lembar kerja siswa harus tersedia setiap pembelajaran supaya memudahkan siswa namun dewasa ini guru hanya menggunakan lembar kerja siswa dari penerbit tang isinya latihan soal-soal. Sebanyak $60 \%$ pemahaman guru tentang evaluasi/ penilaian dikategorikan "cukup", hal ini dikarenakan guru setiap pembelajaran harus ada penilaian terhadap siswa.

Dari hasil rekapan data tentang pemahaman guru terhadap perangkat pembelajaran sudah baik namun perlu ditingkatkan karena tugas guru harus mampu membuat perangkat pembelajaran yang inovatif sebelum memberikan materi kepada siswa dengan tujuan proses pemebelajaran di kelas berjalan dengan baik dan siswa mudah memahami materi yang diajarkan.

Silabus adalah rencana pembelajaran pada suatu kelompok mata pelajaran dengan tema tertentu. yang mencakup standar kompetensi, kompetensi dasar, materi pembelajaran, indikator, penilaian, alokasi waktu, dan sumber belajar yang dikembangkan oleh setiap satuan pendidikan berdasarkan Standar isi (SI), dan standar kompetensi kelulusan (SKL) serta panduan penyusunan Kurikulum 2013 (Sofan, 2013). Berdasarkan Permendikbud No.22 tahun 2016 Silabus disusun berdasarkan standar isi, yang didalamnya untuk mata pelajaran SMA yaitu: Identitas mata pelajaran, identitas sekolah, kompetensi inti, kompetensi dasar, materi pokok, pembelajaran, penilaian, alokasi waktu, sumber belajar.

Menurut Permendikbud nomor 65 Tahun 2013 tentang standar proses, Rencana Pelaksanaan Pembelajaran (RPP) adalah rencana kegiatan pembelajaran tatap muka untuk satu pertemuan atau lebih. RPP dikembangkan dari silabus untuk mengarahkan kegiatan pembelajaran peserta didik dalam upaya pencapaian kompetensi dasar. Setiap pendidik pada suatu pendidikan berkewajiban menyusun RPP secara lengkap dan sistematis agar pembelajaran berlangsung secara interaktif, Inspiratif, menantang, menyenangkan, efisien, serta memotivasi siswa untuk berpatisipasi aktif, kreativitas dan kemandirian sesuai dengan bakat, minat, dan perkembangan fisik serta psikologis siswa. RPP disusun berdasarkan KD atau subtema dan dilaksanakan dalam satu kali pertemuan atau lebih. Menurut Permendiknas Nomor 41 Tahun 2007, komponen RPP adalah: Identitas mata pelajaran, Standar Kompetensi, Kompetensi Dasar, Indikator pencapaian kompetensi, Tujuan pembelajaran, Materi ajar, Alokasi waktu, metode pembelajaran, kegiatan pembelajaran, penilaian hasil belajar, dan sumber belajar.

Handout / bahan ajar menyajikan keseluruhan materi yang harus dipelajari. Serta memunculkan komponen yang diperlukan dalam pembelajaran yang meliputi: tujuan pembelajaran/ kompetensi yaitu materi pembelajaran yang mendukung tersusun secara sistimatis tugas dan soal evaluasi (Hermawan, 2015).

LKS digunakan sebagai sarana untuk mengoptimalkan hasil belajar peserta didik dan meningkatkan keterlibatan peserta didik dalam proses belajar-mengajar. diinstrumen Penilaian bertujuan untuk mengumpulkan informasi tentang kemajuan belajar peserta didik. Dalam Permendikbud No. 81A Tahun 2013 tentang Implementasi Kurikulum Pedoman Umum Pembelajaran dijelaskan bahwa penilaian dalam setiap mata pelajaran meliputi kompetnsi pengetahuan, kompetensi keterampilan dan kompetensi sikap. Penilaian dilakukan berdasarkan indikator-indikator pencapaian hasil belajar dari masingmasing domain tersebut.

Ada beberapa teknik dan instrumen penilaian yang digunakan untuk mengumpulkan informasi tentang kemajuan peserta didik baik berupa tes maupun non-tes antara lain tes tertulis, penilaian unjuk kerja, penilaian sikap, penilaian hasil karya, penilaian portofolio dan penilaian diri. Tujuan penggunaan LKS adalah memberi pengetahuan sikap dan keterampilan, mengecek tingkat pemahaman, mengembangkan dan menerapkan materi pelajaran. Sedangkan mamfaatnya adalah mengaktifkan 
peserta didik, sebagai pedoman guru, menambah informasi, mengembangkan keterampilan.

Evaluasi adalah proses pemberian hasil pengukuran dengan cara membandingkan angka dengan kriterial tertentu. Kriteria ini dapat berupa proses atau kemampuan rata - rata untuk kerja kelompok dan berbagai hal lain (Uno, 2013).

Asessesment terbagi menjadi dua yaitu assessment tradisional dan assessment alternativ. Assesment alternativ adalah pengukuran evaluasi hasil belajar siswa yang lain dari pada ujian tradisional yang sudah baku. Misalnya menggunakan ujian "essay" dan dapat menggunakan rubrik pensekoran portofolio, atau observasi.

Berdasarkan uraian diatas maka dapat dikatakan bahwa perangkat pembelajaran adalah suatu alat atau bahan yang disusun dan digunakan oleh guru baik secara individu maupun kelompok agar pelaksanaan pembelajaran berjalan secara sistimatis dan memperoleh hasil yang maksimal.

Menurut Thelen Sumarsih (2003), menyatakan bahwa pembelajaran akan lebih aktif bila siswa dilibatkan dalam mencari dan menyelesaikan berberapa pertanyaan atau masalah. Selain itu pembelajaran lebih bermakna ketika diikuti dalam konteks sosial dan group investigation memberikan kesempatan pada peserta didik untuk mengikuti pertanyaan bermakna dalam kelompok dan teman sebayanya. Belajar bermakna akan mempermudah pemahaman siswa karena siswa dilatih untuk menangkap setiap informasi yang diperoleh kemudian dikaitkan dengan konsep-konsep yang dimiliki sebelumnya sehingga dapat mencapai tujuan yang diharapkan.

Upaya mengatasi siswa agar mampu berperan aktif dalam proses pembelajaran, perlu adanya suatu inovasi dalam menggunakan beberapa pendekatan dan model pembelajaran. Penggunaan model yang tepat akan menentukan efektivitas dan efisiensi suatu proses pembelajaran.

Menurut Inch 61 al. (2006), berpikir kritis adalah sebuah penyelidikan yang bertujuan untuk mengetahui situasi, kejadian, pertanyaan, atau masalah guna membuat hipotesis atau kesimpulan sementara mengenai hal-hal yang diteliti dengan menggabungkan seluruh informasi informasi yang telah diperoleh sehingga dapat diterima kebenarannya. Siswa yang berpikir kritis tidak hanya percaya begitu saja dengan penjelasan guru, tetapi berusaha mempertimbangkan penalarannya dan mencari informasi lain untuk memperoleh kebenaran.

Proses belajar mengajar tidak diartikan sebagai seseuatu yang memberatkan, namun harus menyenangkan dan memberikan makna dan arti untuk siswa. Adapun komponen yang berkaitan dengan sekolah dalam rangka peningkatan kualitas pembelajaran antara lain kepala sekolah, guru, siswa, sarana prasarana dan proses pembelajaran (Yamin, 2008). Siswa akan merasa lebih senang jika didalam proses pembalajaran terjadi interaksi aktif dan memberikan suatu keterampilan untuk dapat dikembangkan setiap individu. Pembelajaran yang monoton merupakan penyebab siswa menjadi pasif dan hasil belajar yang diperolehpun kurang maksimal.

Berdasarkan hasil angket dan wawancara dengan siswa didapatkan: a) bahwa pembelajaran di kelas menjenuhkan karena yang disampaikan; b) guru menyampaiakn hanya sekedar materi sehingga kurang menarik untuk siswa lebih berpikir kritis; c) masalah lain yang timbul yaitu pembelajaran dengan metode ceramah sehingga siswa bosan dan mengantuk di kelas, d) kurangnya praktikum padahal pelajaran biologi harus banyak praktik.

Berdasarkan permasalahan di atas maka diperlukan solusi untuk meningkatkan keterampilan berpkir kritis siswa dengan menggunakan model pembelajaran yang tepat dan menantang pola pikir kritis siswa.

Model pembelajaran adalah suatu perencanaan atau suatu pola yang digunakan sebagai pedoman dalam merencanakan dikelas atau pembelajaran dalam tutorial (Trianto, 2011). Untuk mencapai tujuan. Model pembelajaran merupakan salah satu pendekatan peserta didik secara adaptif. Model pembelajaran sangat erat kaittannya dengan gaya belajar peserta didik (learning style) dan gaya mengajar (teaching style).

Slavin (2005), menyatakan bahwa kelas adalah sebuah tempat kreatifitas kooperatif dimana guru dan murid membangun proses pembelajaran yang didasarkan pada perencanaan mutual dari berbagai pengalaman, kapasitas, dan kebutuhan mereka masing-masing. Partisipasi aktif siswa sangat penting, terutama untuk membuat keputusan yang menentukan tujuan terhadap apa yang mereka kerjakan. Pada proses ini kelompok dijadikan sebagai sarana sosial untuk menentukan tujuan. Slavin (2005:215), menjelaskan bahwa rencana kelompok adalah salah satu metode untuk mendorong keterlibatan maksimal para siswa. Beberapa tipe pembelajaran kooperatif dirancang sedemikian rupa sehingga siswa mendapatkan peran khusus dalam menyelesaikan seluruh tugas dan mempertanggung jawabkan peran khusus tersebut dalam kelompoknya. Tipe pembelajaran seperti ini adalah group investigation. 
Tabel 1. Gambaran Kemampuan Berpikir Kritis Siswa

\begin{tabular}{|c|c|c|}
\hline Aspek - Aspek & Evaluasi & Penilaian \\
\hline $\begin{array}{c}\text { Memberikan Penjelasan } \\
\text { Sederhana (Elementary } \\
\text { Clarification) }\end{array}$ & $\begin{array}{l}40 \% \text { (kurang), siswa menjelaskan hasil pemikiran sendiri masih cenderung } \\
\text { malu-malu dan kurang jelas sehingga kurang dapat dimengerti. }\end{array}$ & $\begin{array}{l}10 \%-40 \%= \\
\text { kurang }\end{array}$ \\
\hline $\begin{array}{l}\text { Membangun keterampilan dasar } \\
\text { (basic support), }\end{array}$ & $\begin{array}{l}\text { 60\% (Cukup), sebeanrnya siswa sudah aktif dan antusias dalam } \\
\text { membangun keterampilan yang dimiliki namun kurang percaya diri atas } \\
\text { kemampuan yang dimiliki. }\end{array}$ & $\begin{array}{l}41 \%-65 \%= \\
\quad \text { cukup }\end{array}$ \\
\hline Menyimpulkan (inference) & $\begin{array}{l}\text { 69\% (Baik), siswa sudah dapat menyimpulkan hasil diskusi, hasil pemikiran } \\
\text { dan hasil praktikum namun masih secara sederhana dan kurang mendalam. }\end{array}$ & $\begin{array}{l}66 \%-80 \%= \\
\text { Baik }\end{array}$ \\
\hline $\begin{array}{l}\text { Membuat penjelasan lebih } \\
\text { lanjut (advanced clarification) }\end{array}$ & $\begin{array}{l}\text { 65\% (cukup), siswa sebagain sudah ada yang paham untuk melanjutkan } \\
\text { penjelasannya/ gagasan yang ingin dikembangkan. }\end{array}$ & $81 \%-100=$ \\
\hline $\begin{array}{c}\text { Strategi dan taktik (strategy and } \\
\text { tactics) }\end{array}$ & $\begin{array}{l}70 \% \text { (baik), sebagain besar siswa sudah memiliki strategi dan taktik } \\
\text { tersendiri dalam menyampaikan gagasan/idenya namun masih belum detail } \\
\text { dan kesusahan dalam merangkai kata untuk dijadikan suatu argument/ } \\
\text { jawaban. }\end{array}$ & sangat baik \\
\hline
\end{tabular}

Salah satu upaya untuk meningkatkan kemampuan berfikir kritis siswa adalah dengan melibatkan siswa secara aktif dalam proses pembelajaran, salah satu model perangkat pembelajaran yang relevan untuk konteks tersebut adalah dengan pendekatan Model Group Investigation (GI) yakni model belajar kooperatif yang berpusat pada siswa, dimana menempatkan siswa ke dalam kelompok secara heterogen. Dalam pendekatan ini siswa didorong untuk berpartisipasi aktif dalam menggali informasi dan menemukan jawaban atas masalah secara kolektif.

Metode Grup Investigation paling sedikit memiliki tiga tujuan yang saling terkait: a) Group Investigasi membantu siswa untuk melakukan investigasi terhadap suatu topik secara sistematis dan analitik. Hal ini mempunyai implikasi yang positif terhadap pengembangan keterampilan penemuan dan membentu mencapai tujuan. b)Pemahaman secara mendalam terhadap suatu topik yang dilakukan melaui investigasi. c) Group Investigasi melatih siswa untuk bekerja secara kooperatif dalam memecahkan suatu masalah. Dengan adanya kegiatan tersebut, siswa dibekali keterampilan hidup (life skill) yang berharga dalam kehidupan bermasyarakat. Jadi guru menerapkan model pembelajaran GI dapat mencapai tiga hal, yaitu dapat belajar dengan penemuan, belajar isi dan belajar untuk bekerjas secara kooperatif.

Investigation adalah proses yang dilakukan seseorang, dari hasil penyelidikannya, serta dapat membandingkannya hasilnya dengan orang lain. Kegiatan diskusi di kelas akan menghasilkan berbagai alternatif jawaban dan argumentasi yang berdasar pada pengalaman siswa. Group investigation (investigasi kelompok) adalah model belajar kooperatif yang menempatkan siswa ke dalam kelompok secara heterogen dilihat dari perbedaan kemampuan dan latar belakang yang berbeda baik dari segi gender, etnis, dan agama untuk melakukan investigasi terhadap suatu topik (Eggen dan Kauchak dalam Harisantoso (2005).

Dalam berpikir kritis, setiap orang memiliki sudut pandang yang berbeda. Hal ini karena adanya perbedaan latar belakang individu, pemikiran, pengalaman dan tingkah laku. Saat melakukan proses berpikir, maka akan terjadi penggabungan informasi dan gagasan bam ke dalam satu sudut pandang, konsep dan asumsi yang dimiliki. Dari kombínasi pertanyaan, pengujian, penelitian, dan pemahaman, dapat ditarik kesimpulan. Dengan tindakan yang didasarkan pada pengetahuan yang dimiliki siswa, penelitian, dan pembicaraan yang dilakukan, siswa akan dapat menafsirkan data dan menyimpulkan informasi yang diperoleh. Proses menafsirkan dan menyimpulkan merupakan cara menyajikan data dan petimbangan untuk mencapai tujuan yang diharapkan. Siswa harus mampu menentukan pengaruh dari tindakan yang dilakukan dan mengetahui konsekuensi yang mungkin terjadi.

\section{KESIMPULAN}

Wawasan dan pengetahuan guru biologi tentang terkait perangkat pembelajaran masih sangat kurang, guru perlu sosialisasi dan refrensi acuan dalam mengembangkan perangkat pembelajaran. Penggunaan perangkat pembelajaran pada proses pembelajaran masih kurang. Kurangnya keterampilan siswa dalam berpikir kritis.

Berdasarkan simpulan disarankan untuk mengembangkan perangkat pembelajaran berbasis group investigation. Guru biologi sebaiknya menggunakan model pembelajaran berbasis group investigation disinkronkan dengan materi yang membuat berpikir siswa. Guru biologi harus melatih siswa supaya berpikir kritis.

\section{DAFTAR PUSTAKA}

Depdikbud, 2013. Peraturan Menteri Pendidikan dan Kebudayaan Republik Indonesia No.81A Tahun 2013 tentang Implementasi Kurikulum Pedoman Umum Pembelajaran. Kemendikbud. Jakarta.

Depdikbud, 2013. Peraturan Menteri Pendidikan dan Kebudayaan Republik Indonesia No.65 Tahun 2013 tentang Standar Proses Pendidikan DasarDan Menengah. Kemendikbud. Jakarta.

Depdikbud, 2016. Peraturan Menteri Pendidikan dan Kebudayaan Republik Indonesia No.22 Tahun 2016 
tentang Standar Proses Pendidikan Dasar dan Menengah. Kemendikbud. Jakarta.

Eggen, Kauchak. 2005. Group Investigation. Bandung: Cakrawala Persaja.

Inch. 2006. Berpikir Kritis. Jakarta: Eralngga.

Permendiknas No. 41 Tahun 2007, Penddikan di Indonesia.

Sani. 2013. Pendidikan Yang Berkualitas. Bandung. Jaya Cipta.

Sanjaya. 2006. Pembelajaran dalam Implementasi Kurikulum Berbasis Kompetensi. Bandung: Kencana.

Slavin. 2006. Cooperative Learning. Bandung. Nusa Media.

Sofan, A. 2013. Pengembangan dan Model Pembelajaran dalam Kurikulum 2013. Surabaya: PT. Prestasi Pustakarya.

Trianto. 2010. Model Pembelajaran Terpadu. Surabaya: PT. Bumi Aksara.

Thelen, Sumarsih. 2003. Pembelajaran Aktif Melalui Group Investigation. Jakarta. Mulya Pustaka.

Uno, Hamzah B. 2009. Perencanaan Pembelajaran. Jakarta: PT. Bumi Aksara.

Yamin, Martinis. 2008. Teknik mengembangkan Kemampuan Individual Siswa. Jakarta: Gaung persada Press.

Zuhdan dkk. 2011. Pengembangan Perangkat Pembelajaran Sains. Terpadu. Untuk Meningkatkan Kognitif, Keterampilan Proses, Kreativitas Serta Menerapkan Konsep Ilmiah Peserta Didik SMP. Yogyakarta: UNY 